\title{
Editorial
}

\section{The Launch of Eclética Química Journal}

From 1976 to 2016, Eclética Química published its articles mainly in Portuguese although accepting publications in English or Spanish. Over the last years, it became clear that innovation was required to keep up the mission started some decades ago.

New Editors and a new Editorial Board, with Brazilian and foreign scientists, are assuming the new challenges to move the now called Eclética Química Journal (EQJ) forward. An online process has been implemented through the OPEN JOURNAL SYSTEM (OJS) that will allow handling all processes from the manuscript submission to the online publication in a secure, agile, consistent and low cost system. Starting 2017, the Journal publishes only in English, with a new structure and layout.

We are in the process to attributing a Digital Object Identification (DOI) to all articles published since 1976 that still do not have one. DOI is now required for bibliographic references, the corresponding Open Researcher and Contributor ID (ORCID) is being linked to the authors full names, and the reference number cited in the text is now linked to the references list.

Eclética Química Journal is a peer-reviewed scientific journal that does not charge authors article processing fees. All information about the Journal as well as Instructions on how to create an account and submit an article through the submission online system are available at EQJ's website.

The journal page can also be visited through the website of the Institute of Chemistry and Ulrichs web. With the affiliation of the Institute of Chemistry - UNESP Araraquara to the BRAZILIAN ASSOCIATION OF SCIENTIFIC EDITORS - ABEC, on 09/19/2017, Eclética Química Journal can be visited on the ABEC Portal (click on PoPA). EQJ can also be found in Google Scholar and in Google Analytics.

We hope you join us in this new endeavor and kindly invite you to submit your manuscripts to Eclética Química Journal.

Assis Vicente Benedetti Editor-in-Chief of EQJ 